\title{
The Emplementation of Health Protocol Facilities through Handwashing and Social Distancing Education in The Tourism Area of Pecel Kampong, Ngerangan Village Klaten Regency
}

\author{
Novia Sari Ristianti 1,a), Nurhadi Bashit ${ }^{2)}$, Desyta Ulfiana ${ }^{3)}$, Grandy Loranessa \\ Wungo ${ }^{1)}$, Fauzi Janu Amarrohman 2), and Hardi Wibowo ${ }^{3)}$ \\ ${ }^{1}$ Urban and Regional Planning Department, Engineering Faculty, Diponegoro University, Semarang, \\ Indonesia \\ ${ }^{2}$ Geodetic Engineering Department, Engineering Faculty, Diponegoro University, Semarang, Indonesia \\ ${ }^{3}$ Civil Engineering Department, Engineering Faculty, Diponegoro University, Semarang, Indonesia \\ a)Corresponding Author: novia.sari@live.undip.ac.id
}

\begin{abstract}
The COVID-19 pandemic has plagued the entire world, including Indonesia. The step to breaking the spread chain of COVID-19 is to apply health protocols such as handwashing and social distancing. The Covid-19 case in Klaten Regency Central Java for ten weeks until early February 2021 with the status of the Red Zone and death rate is 14.1 percent. Ngerangan Tourism Village has a thematic kampong with culinary and nature attractions, such as Pecel Kampong. The number of visitors reaches 600 tourists per day. This causes tourist sites to be clusters most prone to the spread of COVID-19 and must be equipped with adequate health protocols. Therefore, this service aims to implement health protocols during the Covid 19 pandemic through hand washing and social distancing. The service method has three stages, namely information, guidance, and habitual independence. The output of this service is in the form of technology that is socialized and donated in handwashing behavior in the form of 3 portable footstep sinks, four jerry cans of handwashing soap, one hand washing educational banner, and one banner for implementing health protocols. Meanwhile, the technology that was socialized and granted in the implementation of Social Distancing was in the form of 1 banner for implementing social distancing and 20 stickers indicating the implementation of social distancing.

Keywords: Covid-19, health protocols, handwashing, social distancing
\end{abstract}

\section{INTRODUCTION}

The prevention of the transmission of the COVID-19 disease requires the public to implement health protocols strictly (Karo, 2020; Mahardhini, 2020). Proper handwashing and Social Distancing are expected to break the chain of the spread of Covid 19 effectively (Azzahra et al., 2020; Farokhah et al., 2020; Faura Dea Ayu Pinasti, 2020; Mardhia et al., 2020; Rahmah et al., 2020; Sembiring, Rinawati; Suryani, 2020; Triguno et al., 2020). Handwashing with soap and water is a preventive and effective measure to prevent disease transmission, mechanically remove dust and dirt from the skin surface, and reduce the number of diseasecausing microorganisms such as viruses, bacteria, and other parasites on the hands (Desiyanto \& Djannah, 2013; Ristianti et al., 2021; Syah et al., 2020; Tabi'in, 2020). Meanwhile, the implementation of social distancing from the crowd by maintaining a distance of at least 6 feet (2 meters) can reduce the possibility of contact between the infected and the uninfected to minimize the rate of transmission and death (Ahmed et al., 2018; Farboodi et al., 2020; Glass et al., 2006).

The Ngerangan tourist village in Klaten has natural and culinary attractions. There are many thematic kampongs. One of them is Pecel Kampong, with the number of visitors on weekends reaching 600 tourists. Pecel Kampong is very potential and vulnerable as a place for Covid-19 transmission because it has not been supported through implementing health protocols facilities, such as handwashing facilities, appeal banners, the application of $5 \mathrm{M}$, the absence of social distancing arrangements, and also strict screening before entering tourist attractions. 
Therefore, this service activity regarding the application of health protocols through handwashing and social distancing can apply during the Covid-19 pandemic. The expectation is that tourism actors, both managers, stakeholders, and tourists, are aware of the dangers of Covid-19 transmission at tourist attractions by implementing health protocols with handwashing and social distancing.

\section{METHOD}

Through handwashing and social distancing, the implementation of health protocols was carried out in Pecel Kampong through several implementation stages. These stages include:

1. Stage I Information. There will be initial socialization regarding how to transmit the Covid19 virus, how to prevent the spread of the Covid-19 virus, and education about the right step of handwashing and applying social distancing. It was expected that the target of the service community could understand the goals and achievements of the service community activities carried out by the Students Advisory Agency team of Engineering Faculty Diponegoro University.

2. Stage II Guidance. There will be inviting the target of the service community for guidance on the implementation of health protocols. First, guidance on washing hands properly with clean water and soap using a stomp portable sink. The introduction of the stomp portable sink is expected to educate the public that being a stomp portable sink can reduce hand touch and be safer. There are six steps of proper handwashing has taught in this stage. Second, guidance on implementing social distancing by setting a distance of 2 meters for visitors. This distance setting is devoted to tourist zones such as seats to eat and relax, food order queues, entry queues, toilets, and other facilities in tourist attractions. Pecel Kampong's tourists and actors are expected to apply health protocols to minimize cluster crowds on tourism.

3. Stage III Independence and Habitual. The Students Advisory Agency team of Engineering Faculty Diponegoro University will conduct the evaluation and monitoring process regarding handwashing properly using a stomp portable sink and applying social distancing to visitors in the Pecel Kampong as a tourism area.

\section{RESULTS AND DISCUSSION}

Community service activity is chaired by Novia Sari Ristianti, ST, MT (the Students Advisory Agency team of Engineering Faculty Diponegoro University). The community service activity was carried out in three stages. First, the information described previously then conducts socialization regarding initial understanding and providing information to tourism actors in Pecel Kampong regarding the spreads of covid-19 transmission in tourist areas and steps for implementing health protocols in tourist areas. This service community was expected to provide initial information to tourism actors to understand the importance of implementing health protocols in tourist areas during the Covid-19 pandemic.

Second, in the form of practical guidance for tourism actors in Pecel Kampong. The practical guidance consists of two activities. There are mentoring the practice of washing hands using a portable sink and assisting in implementing social distancing to visitors to Pecel Kampong. The handwashing grant includes three stomp portable sinks, two banners for handwashing information, one banner for covid-19 education, and four jerry cans of hand sanitizer. Meanwhile, the grant of social distancing facilities is twenty marking stickers of social distancing signage and one banner of social distancing education. The service community team leader shows step by step sequentially how to wash hands properly and how to use a stomp portable sink. The washing hands practice in a sequence and correctly using running water and liquid soap. The team also provides ways to implement social distancing by showing tourist areas affixed with a marking sticker.

Third, at the independence and habitual stages, the service community team evaluated the application of health protocols. There are hand washing practices and social distancing 
practices in Pecel Kampong. An evaluation of the health protocol practice effectiveness on behavioral changes in Pecel Kampong as tourism agent.

\section{CONCLUSIONS AND RECOMMENDATIONS}

The Students Advisory Agency Team of Engineering Faculty Diponegoro University organized community service activities to implement health protocols. There are three stages of handwashing practices and social distancing practices in Pecel Kampong. There are information, guidance, and habitual independence. The expected is that tourism actors can correctly and adequately implement health protocols. The service community team also provided grants for supporting facilities to implement health protocols. The handwashing grant includes three stomp portable sinks, two banners for handwashing information, one banner for covid-19 education, and four jerry cans of hand sanitizer. Meanwhile, the grant of social distancing facilities is twenty marking stickers of social distancing signage and one banner of social distancing education.

\section{ACKNOWLEDGMENTS}

The author was grateful to the Chairman of BumDes Ngerangan, Mr. Gunadi, and the tourism actor of Pecel Kampongs for their cooperation as service partners. The grateful also given to the Engineering Faculty Diponegoro University for funding to The Students Advisory Agency Team for the 2021 Fiscal Year.

\section{REFERENCES}

Ahmed, F., Zviedrite, N., \& Uzicanin, A. (2018). Effectiveness of workplace social distancing measures in reducing influenza transmission: A systematic review. BMC Public Health, 18(1), 1-13. https://doi.org/10.1186/s12889-018-5446-1

Az-zahra, D., Sophia, N. A., \& Rahmawati, P. A. (2020). EDUKASI PROTOKOL KESEHATAN NEW NORMAL DAN PENGENALAN DUNIA BISNIS DI TENGAH PANDEMI COVID-19 MELALUI MEDIA SOSIAL. Jurnal Layanan Masyarakat, 4(2), 472-478. https://doi.org/2722-239X

Desiyanto, F. A., \& Djannah, S. N. (2013). Efektivitas Mencuci Tangan Menggunakan Cairan Pembersih Tangan Antiseptik (Hand Sanitizer) Terhadap Jumlah Angka Kuman. Jurnal Kesehatan Masyarakat (Journal of Public Health), 7(2), 75-82. https://doi.org/10.12928/kesmas.v7i2.1041

Farboodi, M., Jarosch, G., \& Shimer, R. (2020). INTERNAL AND EXTERNAL EFFECTS OF SOCIAL DISTANCING IN A PANDEMIC. https://doi.org/10.1017/CBO9781107415324.004

Farokhah, L., Ubaidillah, Y., \& Yulianti, R. A. (2020). Penyuluhan Disiplin Protokol Kesehatan Covid-19 Di Kelurahan Gandul Kecamatan Cinere Kota Depok. Seminar Nasional Pengabdian Masyarakat LPPM UMJ, 1-8. https://doi.org/2714-6286

Faura Dea Ayu Pinasti. (2020). Analisis Dampak Pandemi Corona Virus Terhadap Tingkat Kesadaran. Wellness and Healthy Magazine, 2(Agustus), 237-249.

Glass, R. J., Glass, L. M., Beyeler, W. E., \& Min, H. J. (2006). Targeted social distancing design for pandemic influenza. Emerging Infectious Diseases, 12(11), 1671-1681. https://doi.org/10.3201/eid1211.060255

Karo, M. B. (2020). Perilaku Hidup Bersih dan Sehat (PHBS). Jurnal Keperawatan Komunitas, 01(01), 40-47. https://doi.org/978-602-202-076-9

Mahardhini, J. (2020). Menjadi Warga Negara yang Baik pada Masa Pandemi Covid-19: Persprektif Kenormalan Baru. JPK : Jurnal Pancasila Dan Kewarganegaraan, 5(2), 65-76. https://doi.org/10.24269/jpk.v5.n2.2020.pp65-76

Mardhia, D., Kautsari, N., Syaputra, L. I., Ramdhani, W., \& Rasiardhi, C. O. (2020). Penerapan Protokol Kesehatan Dan Dampak Covid-19 Terhadap Harga Komoditas Perikanan Dan 
Aktivitas Penangkapan. Indonesian Journal of Applied Science and Technology, 1(9), 80-87.

Rahmah, S. F., Mahda, D. R., Purwati, T., Suryo, B., \& Nasution, A. M. (2020). Edukasi Protokol Kesehatan dalam Menjalankan New Normal di Masa Pandemik Melalui Media Poster. Seminar Nasional Pengabdian Masyarakat LPPM UMJ.

Ristianti, N. S., Ulfiana, D., \& Windarto, Y. E. (2021). EDUKASI IMPLEMENTASI PERILAKU HIDUP BERSIH DAN SEHAT DALAM PENCEGAHAN COVID 19 DI KELURAHAN BANYUMANIK KOTA SEMARANG. Jurnal Pasopati: Pengabdian Masyarakat Dan Inovasi Pengembangan Teknologi, 3(2).

Sembiring, Rinawati; Suryani, D. E. (2020). SOSIALISASI PENERAPAN PROTOKOL KESEHATAN DI MASA PANDEMI DENGAN PEMBAGIAN MASKER KESEHATAN KEPADA PARA PEDAGANG DAN PENGUNJUNG PASAR TRADISIONAL PAJAK SORE PADANG BULAN. Jurnal Abdimas Mutiara, 1(2), 124-130.

Syah, D. Z. R., Utari, D., \& Adinugraha, T. S. (2020). Edukasi Penerapan Protokol Kesehatan Penyelenggaraan Kegiatan Pada Masa Pandemi Covid 19 Di Tpq Masjid Awalulmu'Minin Gamping. Jurnal Pengabdian Masyarakat Karya Husada, 2(2), 28-33. https://doi.org/2656-4211

Tabi'in, A. (2020). Perilaku Hidup Bersih Dan Sehat(Phbs) Pada Anak Usia Dini Sebagai Upaya Pencegahan Covid 19. JEA (Jurnal Edukasi AUD), 6(1), 58. https://doi.org/10.18592/jea.v6i1.3620

Triguno, Y., Ayu, P. L., Wardana, K. E. L., Raningsih, N. M., \& Arlinayanti, K. D. (2020). Protokol Kesehatan Covid-19: Sebagai Upaya Pencegahan Covid-19 Di Area Kerja Pada Karyawan Perkantoran Di Bandar Lampung. Jurnal Peduli Masyarakat, 2(Desember), 173-180. 


\section{APPENDIX}
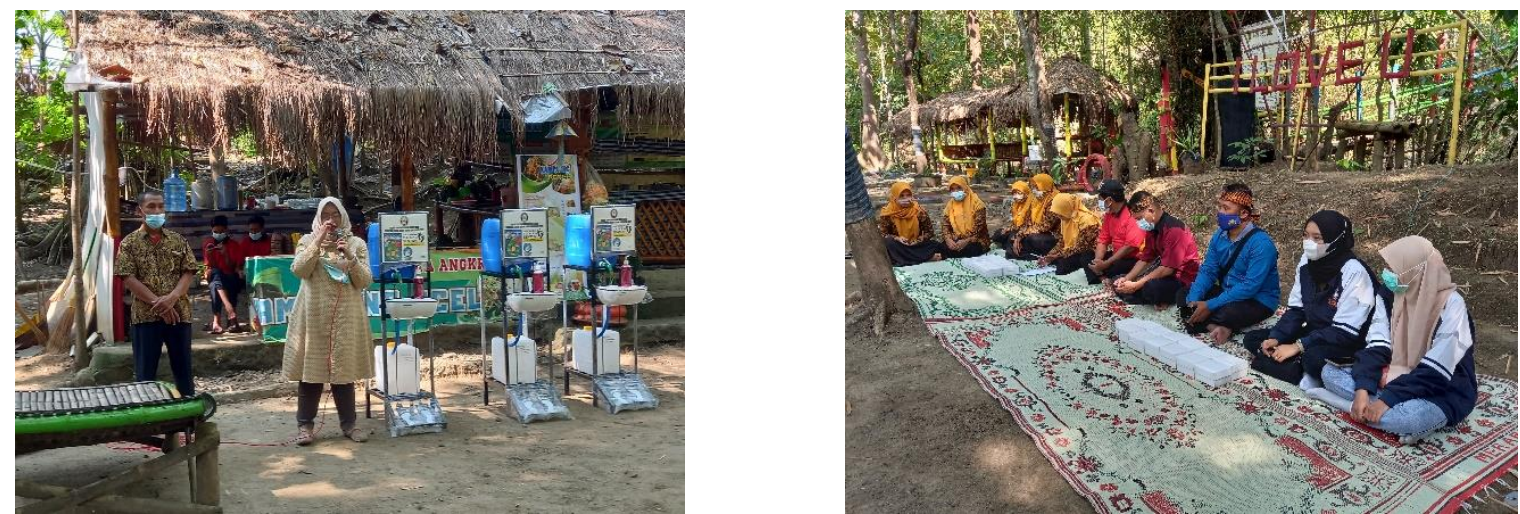

Figure 1. Stage I Information to providing and informing about Covid-19 pandemic, handwashing, and social distancing by Community Service Team of Diponegoro University
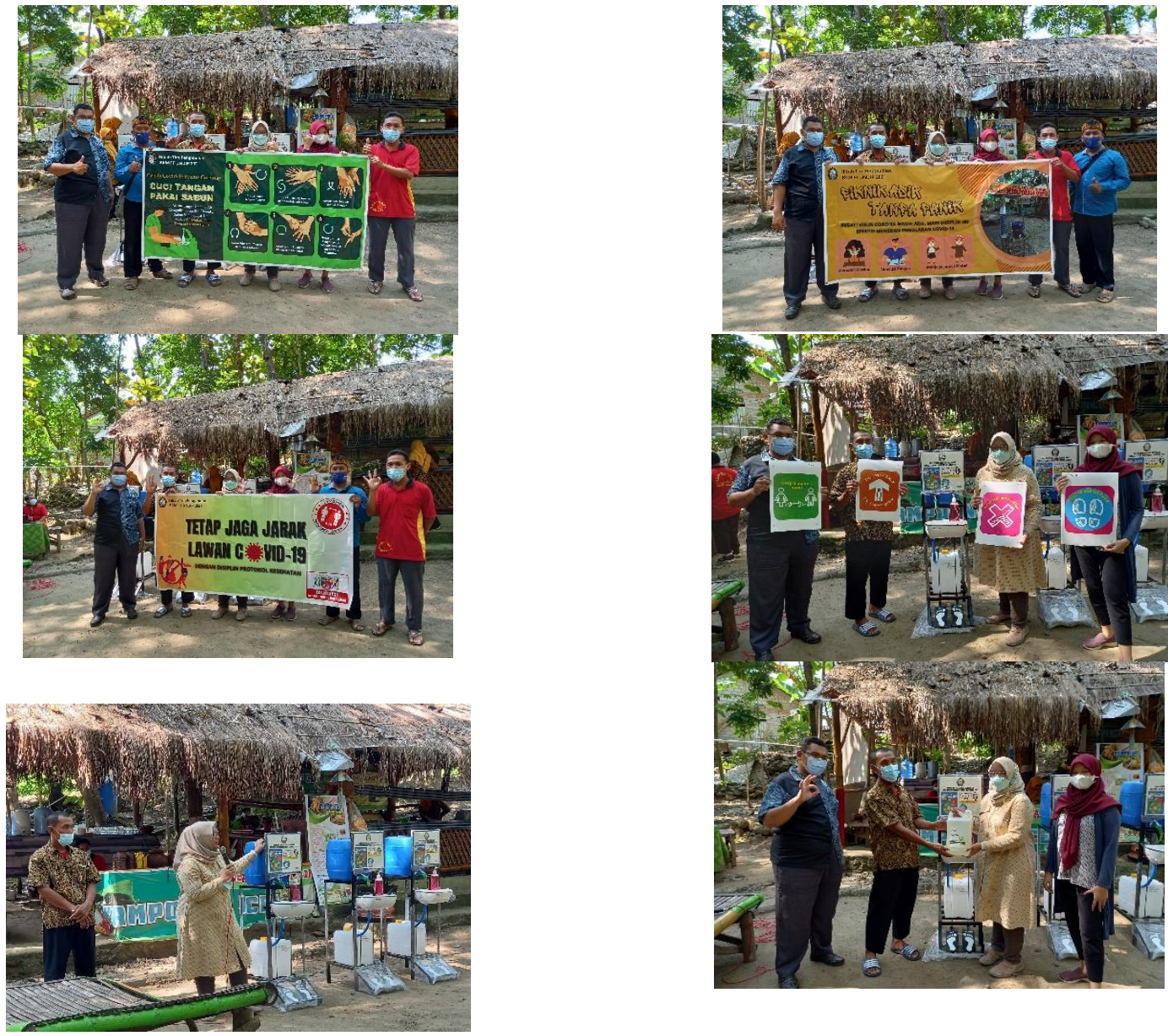

Figure 2. The health protocol facilities grant by Community Service Team of Diponegoro University 

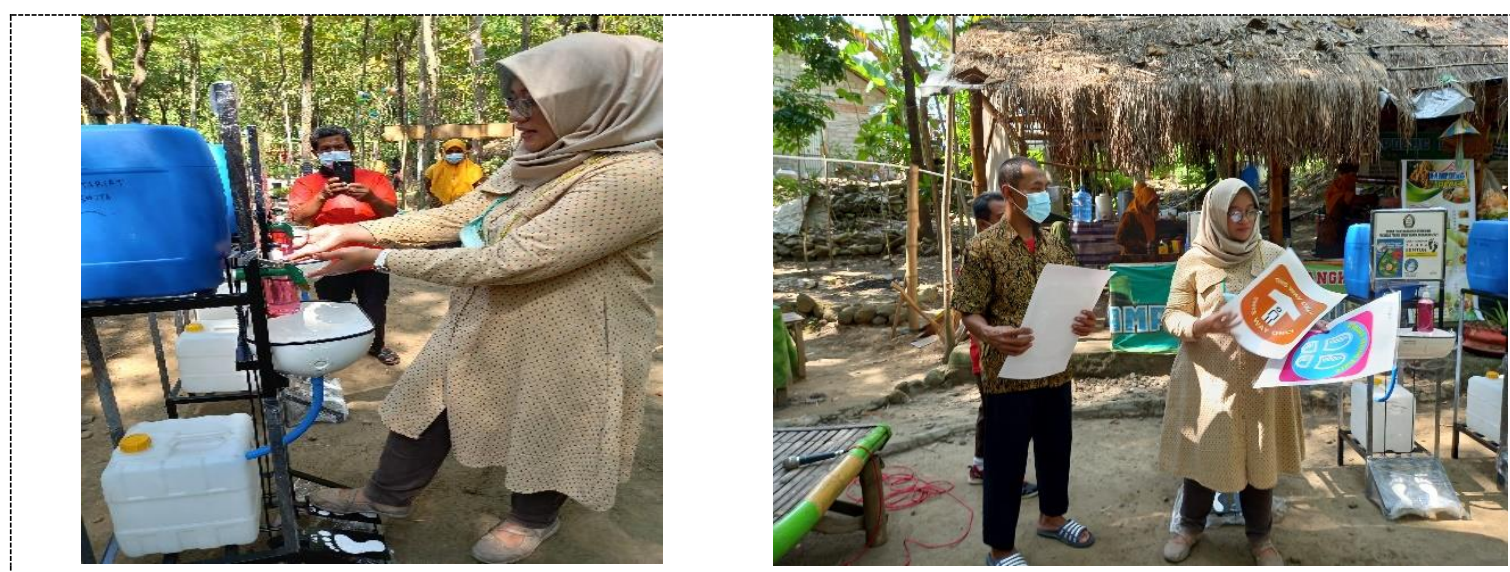

Figure 3. Stage II Guidance to practice about handwashing and social distancing by Community Service Team of Diponegoro University
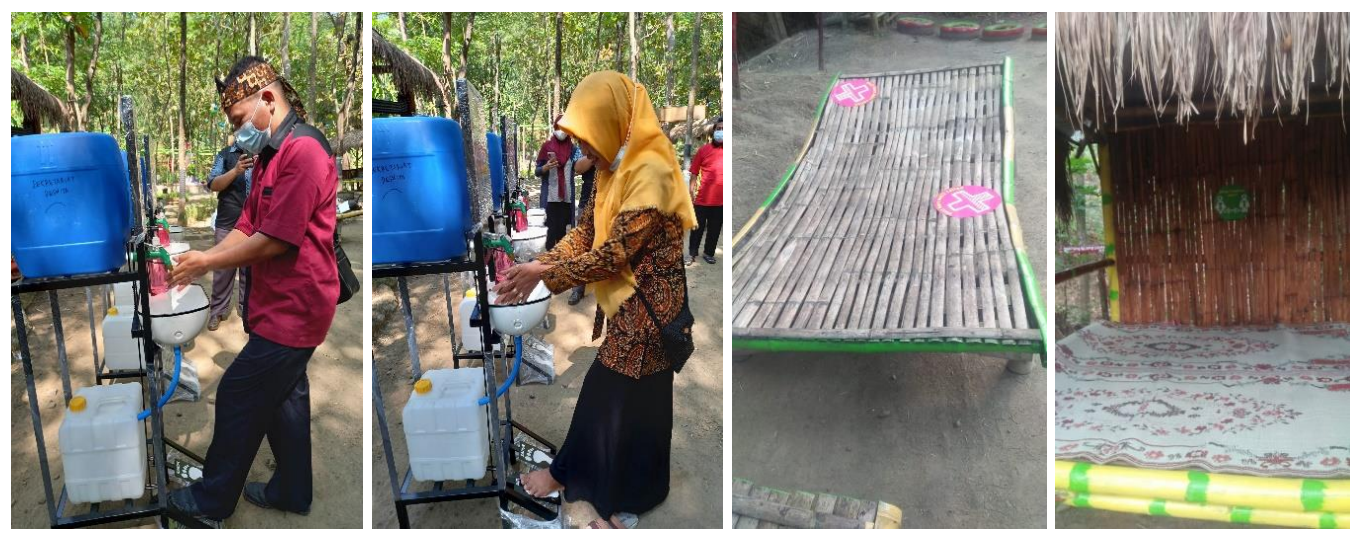

Figure 4. Stage III Independence Habitual about handwashing and social distancing by tourism actors in Pecel Kampong
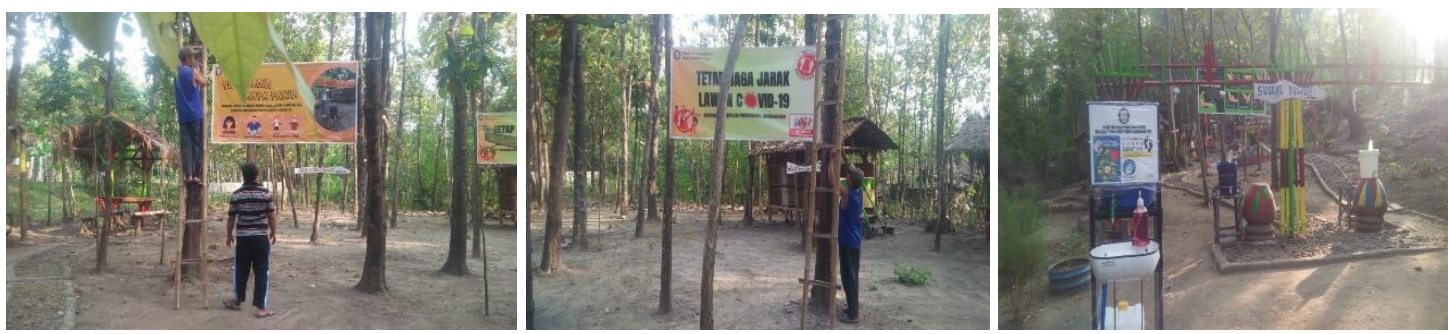

Figure 4. Stage III Independence Habitual about handwashing and social distancing by tourism actors in Pecel Kampong 